\title{
Adenovirus-mediated Expression of a Voltage-gated Potassium Channel In Vitro (Rat Cardiac Myocytes) and In Vivo (Rat Liver) \\ A Novel Strategy for Modifying Excitability
}

David C. Johns, H. Bradley Nuss, Nipavan Chiamvimonvat, Brian M. Ramza, Eduardo Marban, and John H. Lawrence

Division of Cardiology, Department of Medicine, The Johns Hopkins University School of Medicine, Baltimore, Maryland 21205

\begin{abstract}
Excitability is governed primarily by the complement of ion channels in the cell membrane that shape the contour of the action potential. To modify excitability by gene transfer, we created a recombinant adenovirus designed to overexpress a Drosophila Shaker potassium channel (AdShK). In vitro, a variety of mammalian cell types infected with AdShK demonstrated robust expression of the exogenous channel. Spontaneous action potentials recorded from cardiac myocytes in primary culture were abbreviated compared with noninfected myocytes. Intravascular infusion of AdShK in neonatal rats induced Shaker potassium channel mRNA expression in the liver, and large potassium currents could be recorded from explanted hepatocytes. Thus, recombinant adenovirus technology has been used for in vitro and in vivo gene transfer of ion channel genes designed to modify cellular action potentials. With appropriate targeting, such a strategy may be useful in gene therapy of arrhythmias, seizure disorders, and myotonic muscle diseases. (J. Clin. Invest. 1995. 95:1152-1158.) Key words: ion channels • heart $\cdot$ liver $\cdot$ gene therapy $\cdot$ rats
\end{abstract}

\section{Introduction}

Voltage-gated ion channels mediate cellular excitability and thereby play a central role in the function of nerve and muscle (1). When excitable cells are stimulated, they give rise to a tissue-specific electrical response known as the action potential. The duration of the action potential is determined by the balance between inward currents that favor depolarization and outward currents that favor hyperpolarization of the surface membrane. In skeletal muscle and heart, abnormalities of cellular repolarization are now recognized as important factors in several hereditary and acquired human diseases. In a family of myotonic muscle disorders, specific mutations in the skeletal muscle so-

Address correspondence to John H. Lawrence, M.D., Ross 844, The Johns Hopkins University School of Medicine, 720 Rutland Ave., Baltimore, MD 21205. Phone: 410-955-2775; FAX: 410-955-7953; E-mail: jlawrenc@welchlink.welch.jhu.edu

Received for publication 13 February 1995 and accepted in revised form 21 April 1995.

J. Clin. Invest.

(C) The American Society for Clinical Investigation, Inc. 0021-9738/95/08/1152/07 \$2.00

Volume 96, August 1995, 1152-1158 dium channel have been identified that impair inactivation of the sodium channel, delay repolarization, and underlie the repetitive electrical activity of muscle fibers (2-4). The congenital long QT syndrome is characterized by prolonged action potentials, a lengthening of the QT interval on the surface electrocardiogram, and ventricular arrhythmias (5). The long QT syndrome $(\mathrm{LQT})^{1}$ is genetically heterogeneous, with localization to three different chromosomes $(6,7)$. Mutations in a putative potassium channel gene, HERG, cause the chromosome 7-linked form of LQT (8), and mutations in the cardiac sodium channel gene, SCN5, cause the chromosome 3-linked form of LQT (9). In each of these diseases, the clinical phenotype reflects specific alterations in an ionic current that is active during the plateau phase of the action potential. In myocytes from hearts with nonhereditary cardiomyopathy, animal and human studies have consistently demonstrated a significant prolongation of action potentials compared with normal myocytes $(10-12)$. The delayed repolarization seen in these cells arises from a significant decrease in two potassium currents, the transient outward current and the inward rectifier $(13,14)$. It has been hypothesized that the high incidence of sudden death in patients with heart failure is related to these altered membrane currents and an associated lability of cardiac repolarization (12).

Genetic modification of membrane repolarization can be achieved by targeting the action potential plateau. During this time, membrane conductance is low, and even low levels of expression of heterologous ion channels would be capable of modulating the time course of repolarization (15). Several methods potentially suitable for ion channel gene transfer to neurons and muscle have been reported (16-18), including recombinant adenoviruses (19-24). Adenoviral vectors are particularly attractive for this application because they can transform a variety of post-mitotic cell types, multiply to very high titers, and incorporate inserts up to $8.1 \mathrm{kB}$ (large enough for potassium, sodium or calcium channel genes) (25). To investigate the feasibility of adenovirus-mediated modification of cellular repolarization, we have engineered a recombinant adenovirus that encodes an inactivation-defective Drosophila Shaker potassium channel (AdShK), demonstrated its expression in vitro and in vivo, and shown that it can abbreviate action

1. Abbreviations used in this paper: Ad $\beta$ gal, recombinant adenovirus with gene for $\beta$-galactosidase; AdLuc, recombinant adenovirus with gene for luciferase; AdShK, recombinant adenovirus with gene for Shaker potassium channel; LQT, long QT syndrome; moi, multiplicity of infection; pShK, plasmid with gene for Shaker potassium channel; RPA, ribonuclease protection assay; RSV, Rous sarcoma virus long terminal repeat; TEA, tetraethylammonium; pfu, plaque forming units. 
potential duration in infected neonatal cardiac myocytes. This general approach may prove useful in gene therapy of disorders of excitability.

\section{Methods}

Adenovirus vector construction. The coding sequence for the Drosophila Shaker Kv1.1 potassium channel gene (ShK) containing a deletion (encoding amino acids 6-46) that removes fast inactivation and a mutation (T449Y) that increases the channel sensitivity to tetraethyl ammonium ion (TEA) was provided by G. Yellen (Harvard University, Cambridge, MA) (26). To optimize expression, the 5' and 3' noncoding sequences were removed by introducing unique restriction sites at the translational start and stop sites using PCR mutagenesis. The resulting ShK fragment (1854 bp) was cloned into pSL301 (Invitrogen, San Diego, CA), sequenced, and subcloned into the vector pE1RSV, a modified version of $\mathrm{p} \triangle \mathrm{E} 1 \mathrm{sp} 1 \mathrm{~B}$ (obtained from F. Graham, McMaster University, Hamilton, Ontario) that incorporates the Rous sarcoma virus long terminal repeat (RSV) promoter (580 bp), a multiple cloning site (50 bp), and the polyadenylation signal ( $226 \mathrm{bp}$ ) from bovine growth hormone between adenovirus E1 recombination sequences (Fig. $1 a$ ). This plasmid, denoted pShK, was cotransfected with pJM17 into HEK293 cells using lipofectamine (Life Technologies, Gaithersburg, MD) (27). The pJM17 plasmid contains the full human adenovirus serotype 5 genome with an additional 4.3-kb insertion (pBRX, encoding ampicillin and tetracycline resistance) within the $\mathrm{E} 1$ region. The size of the $\mathrm{pJM} 17$ adenoviral genome $(40.3 \mathrm{~kb})$ exceeds $105 \%$ of that of wild-type adenovirus and therefore pJM17 cannot be packaged into infectious virions (28). Homologous recombination between $\mathrm{pShK}$ and $\mathrm{pJM} 17$ replaced portions of the adenoviral E1 region and $\mathrm{pBRX}$ with the desired gene insertion (2.7 kb) to make AdShK (29). This recombination reduced the size of the adenoviral genome so that infectious virions could be produced and also removed E1 sequences critical for viral replication so that AdShK was replication-deficient. Cells were incubated for 10-14 d until plaques appeared. Plaques were picked through agar overlays and expanded in HEK293 cells. For large scale preparations, 1-3 liter spinner flasks of HEK293NS cells (F. Graham) were used for virus amplification. The cells were lysed by freeze-thawing five times to release virus. The resulting supernatant was purified on a $\mathrm{CsCl}$ step cushion made by layering three densities of $\mathrm{CsCl}(1.25,1.33$, and 1.45 grams $/ \mathrm{ml})$. After centrifugation at $50,000 \mathrm{~g}$ for $4 \mathrm{~h}$ at $14^{\circ} \mathrm{C}$, a band of virus at the interface between the 1.33 and 1.45 grams $/ \mathrm{ml}$ layers was removed, re-centrifuged at $300,000 \mathrm{~g}$ for $4 \mathrm{~h}$ at $14^{\circ} \mathrm{C}$, and dialyzed against PBS for $6-12 \mathrm{~h}$ at $4^{\circ} \mathrm{C}$. Titers as high as $10^{13} \mathrm{pfu} / \mathrm{ml}$ were obtained. For AdShK, we confirmed successful insertion of the ShK gene cassette by restriction enzyme digestion and by ribonuclease protection assays (described below).

The AdLuc virus (30) containing the luciferase gene with the CMV immediate early promoter was provided by B. Gerard (University of Texas Southwestern, Dallas, TX) and the Ad $\beta$ gal virus (22) containing the $\beta$-galactosidase gene with the CMV promoter was provided by $\mathrm{F}$. Graham.

Animals and tissues. HEK293 and 3T3 cell lines at 50-70\% confluency were transfected with pShK using lipofectamine (Life Technologies) according to the manufacturer's instructions. HEK293 cells were infected with AdShK with a multiplicity of infection (moi) of $1 \mathrm{pfu/}$ cell and 3T3 cells were infected with an moi of 50-500 (27). Rat neonatal hearts from pups were minced, dissociated in $1.5 \mathrm{mg} / \mathrm{ml}$ trypsin, and preplated in media containing $5 \%$ fetal bovine serum to remove fibroblasts. The remaining cardiocytes were plated in medium 199 (Mediatech, Washington, DC) with Earle's salts, L-glutamine, and $2 \%$ fetal bovine serum, supplemented with $1.5 \mu \mathrm{M}$ vitamin $\mathrm{B} 12,50 \mathrm{U} / \mathrm{ml}$ penicillin, and $0.1 \mathrm{mM}$ bromodeoxyuridine (31). $1 \mathrm{~d}$ after plating, the cardiocytes were infected for $1-3 \mathrm{~h}$ with media containing recombinant adenovirus (10-100 moi). For in vivo delivery of recombinant adenovirus, transillumination of neonatal rats allowed visual localization of the heart and facilitated the passage of a 30-gauge needle through the chest wall into the heart. The flashback of pulsatile blood into the needle indicated that the needle tip was intravascular. Up to $10^{8} \mathrm{pfu}$ of recombinant adenovirus diluted in a volume of $0.1 \mathrm{ml}$ of PBS were administered. Tissue examination was performed 2-5 d after infection. Hepatocytes were minced, dissociated in $0.05 \%$ collagenase, and plated into PC-1 media (Hycor, Irvine, CA) overnight before transfer to the whole-cell recording bath solution (described below). The consistent high level of luciferase expression in the liver following AdLuc injection suggested that this injection technique reliably disseminated a high titer of virus throughout the animal. We cannot be sure which cardiac chamber was entered, but we expect equivalent peripheral expression following injection into either the left or right heart since there is not a significant firstpass removal of virus in the lungs (19).

Molecular analyses. Total RNA was isolated from both cells and tissues using Trizol reagent (Life Technologies) as per the manufacturer's instructions. Ribonuclease protection assays were performed using the RPAII kit (Ambion, Austin, TX). Ten to twenty micrograms of total RNA was hybridized with a 731-bp probe specific for the 3' end of the ShK gene (protected fragment $=466 \mathrm{bp}$ ) and with a probe for $18 \mathrm{~S}$ ribosomal RNA (Ambion; protected fragment $=80 \mathrm{bp}$ ) to control for the amount of RNA loaded. Protected fragments were separated on $5 \%$ denaturing polyacrylamide gels. Tissue samples from neonatal rats injected with AdLuc were homogenized in cell lysis buffer ( 0.1 gram tissue $/ 300 \mu \mathrm{l}$ buffer) and clarified by centrifugation at $15,000 \mathrm{~g}$. The luciferase assay was performed using the Promega (Madison, WI) luciferase reagent and light emission was measured with a Monolith 2010 luminometer (Analytic Luminescence Laboratory, San Diego, CA). The protein content of each sample was determined using the Bradford method and a Beckman DU640 spectrophotometer (Fullerton, CA). Background luciferase activity was determined as the mean luciferase activity in five hearts and five livers from age-matched uninfected litter mates.

Electrophysiology. Experiments were performed at $21^{\circ} \mathrm{C}$. Wholecell currents were recorded with an Axopatch 200A amplifier (Axon Instruments, Foster City, CA), sampled at $10 \mathrm{kHz}$, and filtered at 500 $2,000 \mathrm{~Hz}(-3 \mathrm{db})$. The pipette contained (in $\mathrm{mM}$ ): $118 \mathrm{~K}$-aspartate, 6.4 $\mathrm{MgCl}_{2}, 5$ EGTA, $4.2 \mathrm{~K}_{2} \mathrm{ATP}, 2.7 \mathrm{CaCl}_{2}, 5$ Hepes, pH 7.2. The potassium currents were recorded in a bath containing (in $\mathrm{mM}$ ): 140 NMG, $5.4 \mathrm{KCl}, 1 \mathrm{MgCl}_{2}$, 10 glucose, 10 Hepes, $0.1 \mathrm{CaCl}_{2}, 0.5 \mathrm{CdCl}_{2}$, pH 7.4. Net membrane currents were recorded using a modified Tyrode's solution comprised of (in $\mathrm{mM}$ ): $140 \mathrm{NaCl}, 5.4 \mathrm{KCl}, 10$ glucose, 1 $\mathrm{MgCl}_{2}, 1 \mathrm{Na}$ pyruvate, $2 \mathrm{CaCl}_{2}, 10 \mathrm{HEPES}, \mathrm{pH}$ 7.4. Series resistance compensation was $80 \%$ during all voltage clamp experiments. The maximum uncompensated voltage error for the largest whole-cell currents $(\sim 7 \mathrm{nA})$ was estimated as $<6 \mathrm{mV}$. For the more typical 2-3 $\mathrm{nA}$ potassium currents, the maximum voltage error was $<3 \mathrm{mV}$.

Spontaneous action potentials were recorded from cells in medium 199 using pipettes that contained (in $\mathrm{mM}$ ): $140 \mathrm{KCl}, 10 \mathrm{NaCl}, 4$ MgATP, $1 \mathrm{MgCl}_{2}, 10$ Hepes, 2 EGTA, pH 7.2. Pipette resistances were 5-6 M . Action potential duration was measured as the time from the overshoot to $50 \%$ repolarization $\left(\mathrm{APD}_{50}\right)$. Action potential parameters in neonatal primary cell cultures, including maximum diastolic potential, $\mathrm{APD}_{50}$, and spontaneous beating frequency, are known to vary from cell to cell and from monolayer to monolayer $(32,33)$. To facilitate comparison between unpaired groups, $\mathrm{APD}_{50}$ was corrected for beating frequency using a simplified version of previously described methods (32). Rate-corrected $\mathrm{APD}_{50}$ was calculated as the absolute $\mathrm{APD}_{50}$ divided by the square root of the interbeat interval normalized by the average interbeat interval for all the cells. This provided values on the same order as the uncorrected $A P D_{50}$ but with less variability, since rate-dependent changes in action potential duration were compensated at least partially.

Pooled data are presented as means \pm SE. Paired or unpaired $t$ tests were used to gauge statistical significance.

\section{Results}

In vitro expression of AdShK. The AdShK recombinant adenovirus contains the Rous sarcoma virus long terminal repeat 


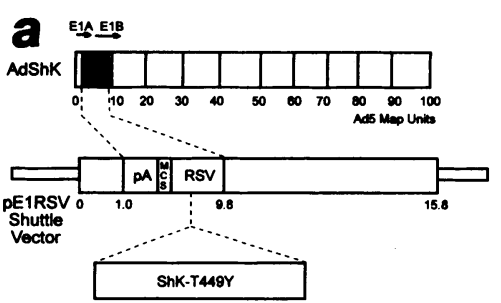

b

ShK

$18 S$

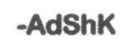

$C$

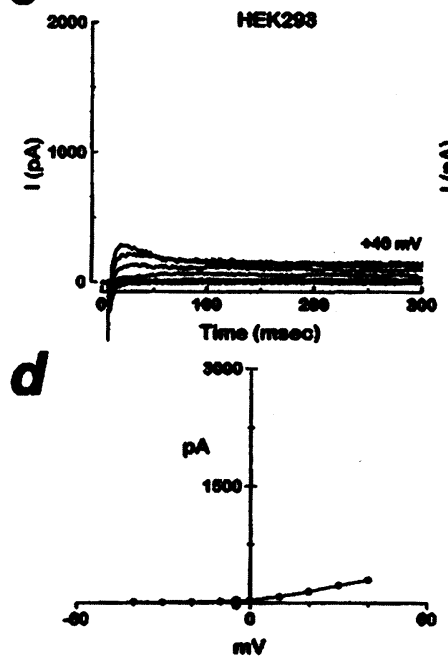

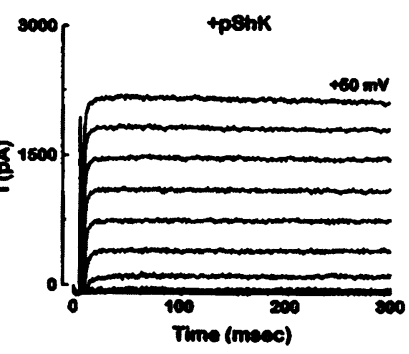

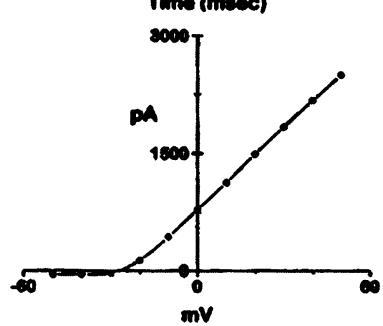

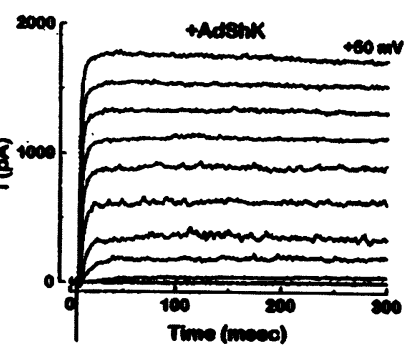

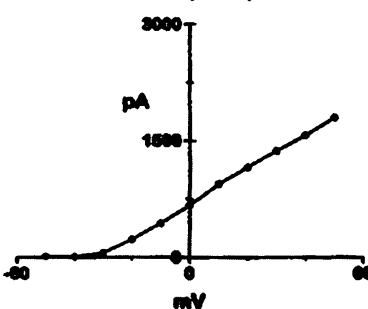

Figure 1. In vitro adenovirus-mediated transcription and translation of the modified Shaker potassium channel in HEK293 cells.

(a) Schematic of the AdShK vector construction. The shuttle vector includes adenoviral E1 sequences $(0-1.0[E 1 A]$ and 9.815.8 map units $[E 1 B])$ flanking the RSV promoter, a multiple cloning site (MCS), and polyadenylation signal $(p A)$. The cDNA encoding an inactivation-defective and TEA-sensitive (due to T449Y mutation) Shaker potassium channel (ShK-T449Y) was cloned into the pE1RSV shuttle vector to form $\mathrm{pShK}$, from which AdShK was derived by homologous recombination in HEK293 cells (see Methods for details). (b) Ribonuclease protection assay performed on HEK293 cells in culture $1 \mathrm{~d}$ after infection with AdShK. The control sample was not infected. The riboprobes are designed to protect a 466-bp fragment from the 3 ' end of the gene insert and an 80-bp fragment from $18 \mathrm{~S}$ ribosomal RNA. The film was overexposed to confirm lack of expression of Shaker-type channels in native HEK293 cells. The two sample lanes are separated by a blank lane. (c) Expression of the ShK potassium current in HEK293 cells at baseline (left), $2 \mathrm{~d}$ after transfection with pShK (middle), and $1 \mathrm{~d}$ after infection with AdShK (right). Whole-cell currents were recorded during membrane depolarizations from a holding potential of $-80 \mathrm{mV}$ to a series of test potentials ranging from -60 to $+60 \mathrm{mV}$. (d) Plots demonstrating the voltage-dependence of peak outward current for the records in $c$.

(RSV) promoter and a noninactivating tetraethylammonium (TEA)-sensitive Shaker potassium channel gene inserted into the viral early region 1 (E1) by homologous recombination in HEK293 cells (Fig. 1 a). E1 sequences include the viral transforming region that is necessary for viral DNA replication. HEK293 is a human embryonic kidney cell line transformed by sheared fragments of adenovirus serotype 5 that constitutively expresses adenoviral E1 gene products and allows propagation of replication-deficient adenoviruses (34). We first sought evidence for adenovirus-mediated potassium channel expression in this cell line where AdShK can direct high levels of expression during a brief interval before cytopathic effects develop. A ribonuclease protection assay (RPA) performed on one 150 ml flask of HEK293 cells $24 \mathrm{~h}$ after infection with AdShK at a moi $\approx 1$ demonstrated a unique protected 466-bp RNA fragment from the $3^{\prime}$ end of the gene insert (Fig. $1 b$ ). We next examined the effects of AdShK in 3T3 cells, a cell line derived from mouse fibroblasts that is not permissive for AdShK growth. An RPA performed on one $150 \mathrm{ml}$ flask of 3T3 cells $48 \mathrm{~h}$ after infection with AdShK (at moi $\approx 50$ and 500 ) produced the same protected fragment (data not shown). These findings demonstrated that AdShK expresses the modified Shaker potassium channel in both permissive and nonpermissive cell lines.

Whole-cell patch clamp recordings in HEK293 cells showed that AdShK-derived potassium channels reached the cell membrane, conducted a large outward potassium current, and were functionally indistinguishable from similar channels expressed by transient transfection. Noninfected HEK293 cells (Fig. $1 c$, left) or those infected with an adenovirus expressing the reporter gene luciferase (AdLuc) (data not shown) consistently exhibited small outward currents that activated only at positive test potentials. Whole-cell recordings from HEK293 cells transfected with a plasmid encoding the ShK channel (pShK) demonstrated peak outward currents up to $2 \mathrm{nA}$ at test potentials of $+50 \mathrm{mV}$ (Fig. $1 \mathrm{c}$, middle) with kinetics that closely match recordings from Xenopus oocytes expressing this channel (26). Outward currents greater than $1 \mathrm{nA}$ at $+50 \mathrm{mV}$ were seen in $\sim 30 \%$ of cells studied, consistent with the expected rate of plasmid-mediated transient transfection in these cells (35). After infection with AdShK, we recorded outward currents similar in amplitude and kinetics to those seen following pShK transfection (Fig. $1 c$, right). Outward currents greater than 1 $\mathrm{nA}$ in amplitude at $+50 \mathrm{mV}$ were observed in 12 of 12 cells from which currents were recorded, as expected since the virus freely replicates in HEK293 cells.

Modification of ionic currents and action potentials by AdShK in cardiac myocytes. Having established that AdShK directs high levels of expression in both permissive and nonpermissive cell lines, we next examined its effects in cultured heart cells. Cardiac myocytes were isolated from one-day-old neonatal rats, infected with AdShK (moi $\approx 100$ ) on day 1 or 2 in primary culture, and studied electrophysiologically on days 2 to 5 . Depolarization to $-40 \mathrm{mV}$ elicited a robust inward sodium current confirming the identity of these cells as cardiac myocytes (Fig. 2 a). Subsequent depolarization to $+40 \mathrm{mV}$ 


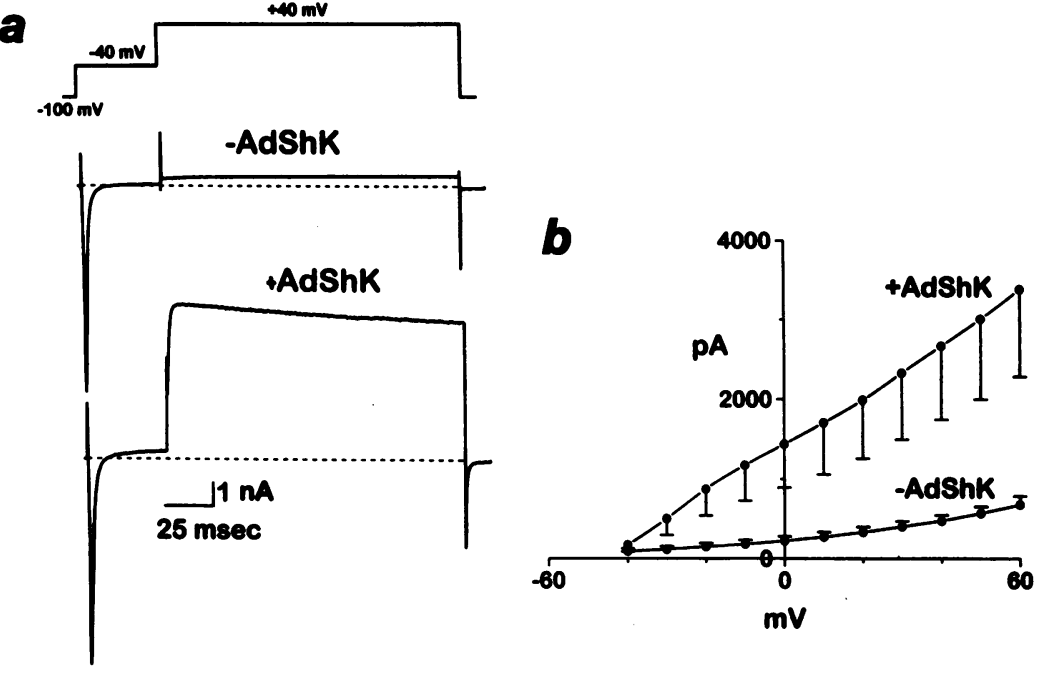

Figure 2. Characterization of in vitro adenovirus-mediated ShK expression in rat neonatal cardiac myocytes. (a) The voltage-clamp protocol (top) is designed to elicit an inward sodium current during the depolarization to $-40 \mathrm{mV}$ and an outward potassium current during the subsequent depolarization to $+40 \mathrm{mV}$. Wholecell current records (below) demonstrate large inward sodium currents in both an uninfected and an AdShKinfected myocyte, but only a robust outward current in the AdShK-infected cell. ( $b$ ) Plot of mean peak outward current $\pm S E$ vs. test potential for control $(n=5)$ and AdShK-infected $(n=5)$ cardiac myocytes. elicited only a small outward potassium current in cells not exposed to AdShK (top) compared with a much larger and more rapidly activating potassium current in cells infected with AdShK (bottom). The plot of peak outward current versus step potential demonstrated that the uninfected heart cells exhibit a relatively small outward current; in contrast, cells infected by AdShK express large outward currents (Fig. $2 b$ ) similar to those seen in AdShK-infected non-excitable cells.

Neonatal rat cardiac myocytes in primary culture exhibit intrinsic pacemaker activity $(32,33)$, enabling us to record spontaneous action potentials. In control cells not infected with AdShK, characteristic cardiac action potentials were observed, and neither the duration nor the frequency of these action potentials was significantly altered by $5 \mathrm{mM}$ TEA (Fig. 3, $a$ and $b$, left). In contrast, action potentials from cells infected with AdShK exhibited a blunted plateau phase and a markedly abbreviated $\mathrm{APD}_{50}$. These changes were reversibly blocked by $5 \mathrm{mM}$ TEA (Fig. 3, $a$ and $b$, right), a concentration which blocks $\sim 90 \%$ of the current through this Shaker channel (26). The differences in action potential duration and in TEA-responsiveness illustrated in Fig. $3 a$ are representative and statistically significant. Pooled data from five uninfected control myocytes and six AdShK-infected myocytes confirmed the shortening of rate-corrected $\mathrm{APD}_{50}$ at baseline in the AdShK group (Fig. 3 $c)$. Stable impalements were maintained during the application and washout of $5 \mathrm{mM}$ TEA in three cells from each group. The AdShK-infected cells exhibited a consistent increase in ratecorrected $\mathrm{APD}_{50}$ during exposure to TEA (Fig. $3 d$ ), which was fully reversible (not shown); uninfected cells did not respond to TEA (Fig. $3 d$ ). Other action potential parameters showed less consistent differences or none at all. Spontaneous beating frequency was not different in uninfected $(0.61 \pm 0.15 \mathrm{~Hz} ; n$ $=5)$ vs. AdShK-infected myocytes $(0.54 \pm 0.06 \mathrm{~Hz} ; n=6 ; p$ $=0.64$ ), although it did increase during exposure to TEA in each of 3 AdShK-infected myocytes (from $0.51 \pm 0.08 \mathrm{~Hz}$ to $1.04 \pm 0.19 \mathrm{~Hz} ; p=0.06$ ). Maximum diastolic potentials were variable in both groups (consistent with previous results from neonatal heart cells in primary culture; 32,33 ) but, on average, were not different in controls vs. AdShK-infected myocytes $(-58 \pm 10 \mathrm{mV}$ vs. $-67 \pm 22 \mathrm{mV} ; p=$ n.s. $)$.

In vivo expression of AdShK. Delivery of $10^{7}-10^{8} \mathrm{pfu}$ AdShK or AdLuc to 1-d-old neonatal rats was achieved by a direct transthoracic injection into the heart. 2-4 d later, organs and tissues were harvested. Luciferase activity was detected in liver, heart, lung, skeletal muscle and brain (Fig. $4 a$ ). Although small, expression levels in the brain, lung and skeletal muscle were two to three orders of magnitude greater than background, while expression in the liver and heart were four to five orders of magnitude greater than background. Parallel experiments with a recombinant adenovirus expressing $\beta$-galactosidase ( $\mathrm{Ad} \beta$ gal) revealed by visual inspection after transverse sectioning and staining that one-quarter to one-half of the $\beta$-galactosidase activity resulted from direct myocardial injection along the needle track into the heart. Since our data and previous studies (19, 25,30 ) using intravascular delivery of recombinant adenovirus have shown greatest levels of expression in the liver, we sought evidence for in vivo adenovirus-mediated expression of Shaker channels in this organ. From liver tissue harvested two to four days post-infection, an RPA confirmed expression of the Shaker mRNA (Fig. $4 b$ ). Whole-cell patch-clamp recordings revealed small outward currents $(<200 \mathrm{pA})$ in hepatocytes derived from AdLuc-infected rats (Fig. $4 c$ ), but much larger outward currents in hepatocytes isolated from AdShK-infected livers (Fig. $4 d$ ). The voltage-dependence of these currents matched that seen with in vitro AdShK infection (Fig. $1 d, 2 b$ ). However, the decay of current in response to strong depolarizations was consistently more rapid in hepatocytes than that observed in HEK293 or cardiac cells. These differences presumably reflect factors specific to each host cell (e.g., accessory proteins/subunits, changes in potassium channel heteromultimerization with such subunits, posttranslational modification, and/or endogenous gating modifiers).

\section{Discussion}

We have demonstrated that a replication-defective recombinant adenoviral vector directs expression of functional voltage-gated potassium channels following both in vitro and in vivo infection. AdShK replicates to high levels in HEK293 cells that complement the missing adenoviral E1 region and generates a large outward potassium current in this cell line. We also observed robust AdShK-mediated in vitro expression in nonpermissive cells, including 3T3 fibroblasts and rat neonatal cardiac myocytes. In each of these cell types, the kinetics and voltage- 
a
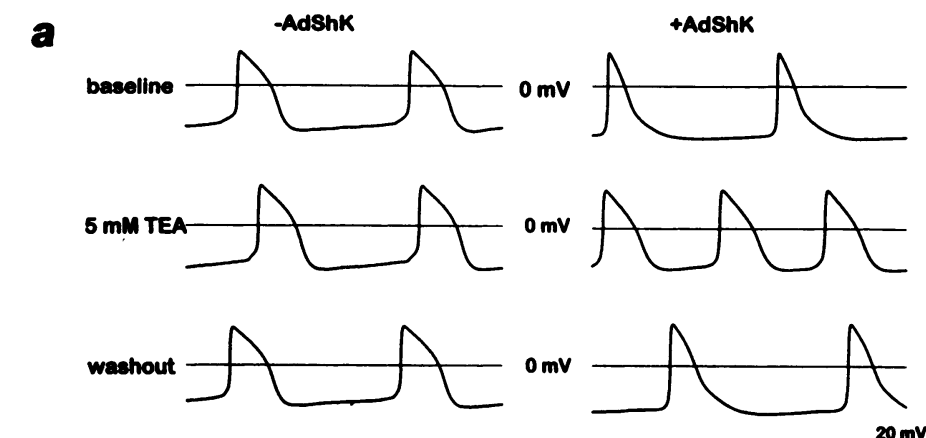

b

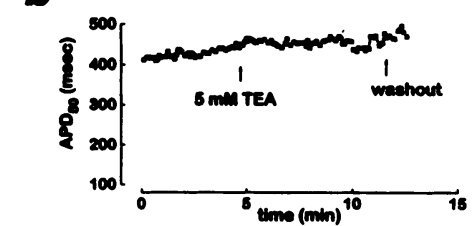

C

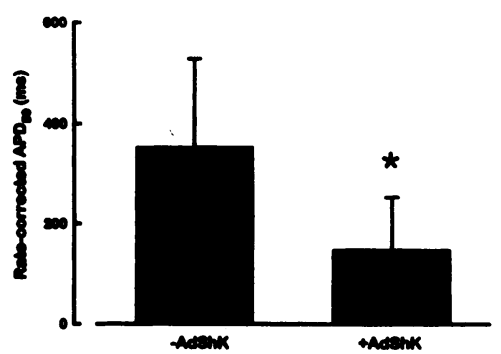

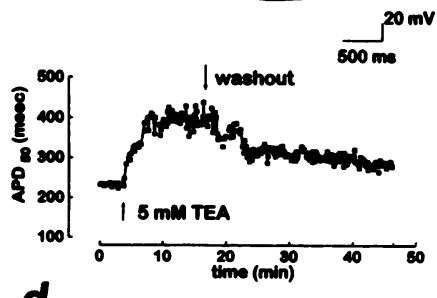

d

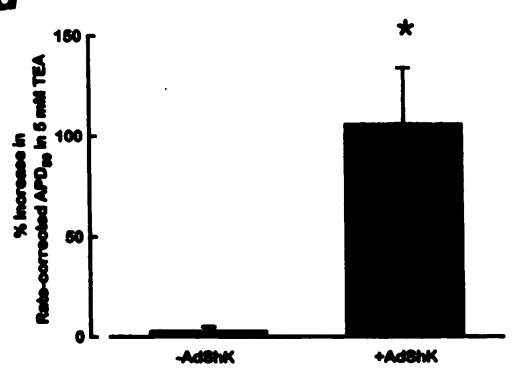

Figure 3. In vitro characterization of AdShK-induced changes in action potential characteristics of neonatal rat cardiocytes. (a) In current clamp mode, action potentials were recorded at baseline, during infusion of 5 mM TEA, and during washout of TEA in a control uninfected myocyte (left) and an AdShK-infected myocyte (right). (b) Plot of the action potential duration $\left(\mathrm{APD}_{50}\right)$ versus time for the cells examined in $a$. (c) Mean $\pm S E$ of rate-corrected $A P D_{50}$ in five uninfected cells and in six AdShK-infected cells. In 3 of 6 infected cells, TEA-sensitivity was not measured to confirm expression of the ShK channel. However, these three cells had a distinct acceleration of the early repolarization phase seen only in cells with TEA-sensitive current. $(d)$ Mean $\pm S E$ of the increase in rate-corrected $A \mathrm{PD}_{50}$ after exposure to $5 \mathrm{mM}$ TEA in four uninfected and three AdShK-infected cells. ${ }^{*} P<0.05$. dependence of the expressed current matched very closely those observed in HEK293 cells transfected with a plasmid encoding the same Shaker gene. In neonatal rat cardiac myocytes, we provide the first evidence that an adenovirus vector encoding an ion channel gene can modulate the contour of the action potential plateau and the duration of the action potential. Expression of the Shaker potassium channel produced a large outward current that accelerated repolarization of the cell membrane. The influence of this heterologous channel was reversed by $5 \mathrm{mM}$ TEA, which specifically blocked the Shaker channel
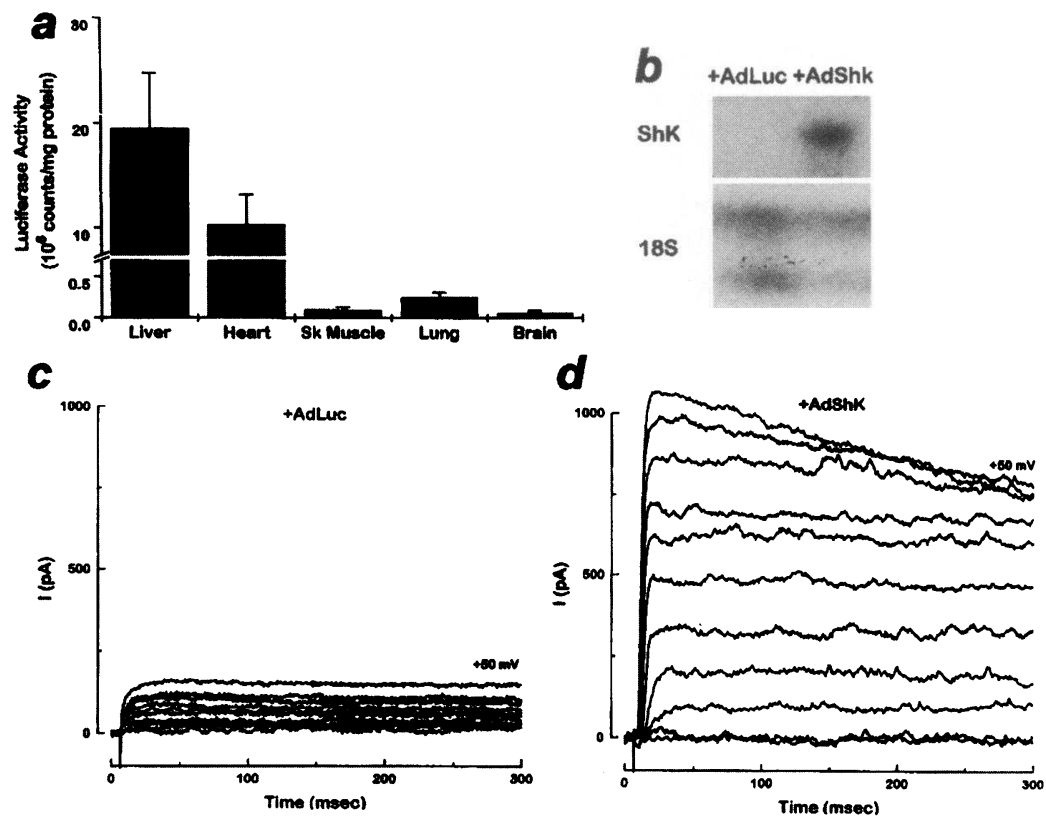

Figure 4. In vivo adenovirus-mediated transcription and expression of the modified Shaker potassium channel. (a) Mean \pm SE luciferase activity per $\mathrm{mg}$ protein in organs harvested $2 \mathrm{~d}$ after intracardiac injection of $10^{7}$ pfu of AdLuc ( $n=8$ animals). The background luciferase activity from hearts and livers of noninfected rats was $288 \pm 3$ counts $(n=10)$. (b) Ribonuclease protection assays performed on liver tissue explanted from neonatal rats $2 \mathrm{~d}$ after transthoracic injection of AdShK $\left(10^{8} \mathrm{pfu}\right)$ or AdLuc $\left(10^{8} \mathrm{pfu}\right)$. The riboprobes were the same as in Fig. 1. When large amounts of ribosomal RNA are present in total RNA (relative to mRNA) the protected 80-bp fragment appears as two distinct bands. A portion of the antisense probe rehybridizes to its complementary sequence and this double-stranded species migrates at a slightly faster rate than the single-stranded RNA (Ambion, technical notes). ( $c$ and $d$ ) Whole-cell currents recorded from acutely dissociated rat hepatocytes $2 \mathrm{~d}$ after transthoracic injection of $10^{8} \mathrm{pfu}$ AdLuc $(c)$ or AdShK $(d)$. The stimulation protocol consisted of depolarizations from a holding potential of $-80 \mathrm{mV}$ to a series of test potentials ranging from -50 to 50 $\mathrm{mV}$. Results in $c$ were confirmed in a total of six cells from AdLuc-infected rats, while $d$ shows data from one of two cells (out of 6 ) from AdShK-infected rats that exhibited outward currents $>500 \mathrm{pA}$ at $+50 \mathrm{mV}$. 
but had no significant effect on native cardiac cells. In the absence of TEA, the spontaneous beating rate in AdShK-infected myocytes did not differ from the beating rate in uninfected myocytes. However, when the Shaker channel was blocked by $5 \mathrm{mM}$ TEA, the beating rate increased. This was unexpected since the Shaker channel is not active at diastolic membrane potentials. Additional experiments will be required to elucidate the mechanism of the changes in beating frequency in AdShK-infected cells during exposure to TEA.

Our results are the first to show that viral gene transfer can be used to alter the complement of ion channels in excitable cells as a means of modifying their pattern of excitation. In the short run, this technical advance should facilitate the exploration of the mechanisms of excitability, even if limited to isolated cells and tissues. Nevertheless, long-term applications rely more on the prospect of in vivo use. We have observed that AdLuc widely disseminates after in vivo delivery into the arterial bloodstream with the greatest levels of expression occurring in the liver, consistent with other studies that have shown high levels of expression of reporter genes in the liver after peripheral administration of adenovirus $(19,25,30)$. Intravascular injection of AdShK results in expression of functional virally encoded potassium channels in the liver. While such an action may itself have subtle phenotypic consequences (hepatocyte membrane potential determines the rate of bile acid uptake [36], for example), the most dramatic effects of ion channel overexpression would be expected in excitable tissues such as heart and brain.

Previous applications of viral gene transfer have as their ultimate goal either the correction of a defined genetic disorder (as in adenosine deaminase deficiency or cystic fibrosis) or the elaboration of potent paracrine or endocrine products (such as erythropoietin or tissue plasminogen activator; see reference 37 for a brief review). The ultimate goal of the present work is fundamentally different: we seek to modify the very phenotype of an end organ, an approach perhaps more analogous with pharmacologic therapy than with conventional gene therapy. The most obvious application, the reversal of genetic ion channel disorders, gives only the narrowest hint of potential therapeutic utility. Creative manipulation of ion channel composition in excitable tissues may be useful to treat disorders not only of excitation but also of contraction, secretion and transcription, all of which are modulated by the cell's complement of ion channels. Successful in vivo application of this technology will require improved delivery methods to achieve high and widespread levels of infection in organs other than the liver, incorporation of tissue-specific promoters to refine targeting of the gene product, and minimization of the virally induced inflammatory response (38). Nevertheless, our results give good reason to expect that viral gene transfer represents a feasible and potentially powerful therapeutic strategy for the modification of excitability in vivo.

\section{Acknowledgments}

We thank Frank Graham, Gary Yellen, and Robert Gerard for providing vectors. We also thank William Guggino and Gordon Tomaselli for their review of the manuscript.

This project was supported by a Johns Hopkins University School of Medicine Institutional Research Grant (J. H. Lawrence). General laboratory support was provided by National Institutes of Health (NIH) RO1 HL-36957 (E. Marban), and salary support by NIH KOH HL-
02639 (J. H. Lawrence), the Maryland Affiliate of the American Heart Association (H. B. Nuss), and the Heart and Stroke Foundation of Canada and the Medical Research Council of Canada (N. Chiamvimonvat).

\section{References}

1. Hille, B. 1992. Ionic channels of excitable membranes. Sinauer Associates, Inc., Sunderland, MA.

2. McClatchey, A. I., P. Van den Bergh, M. A. Pericak-Vance, W. Raskind, C. Verellen, D. McKenna-Yasek, K. Rao, J. L. Haines, T. Bird, R. H. Brown, Jr. and J. F. Gusella. 1992. Temperature-sensitive mutations in the III-IV cytoplasmic loop region of the skeletal muscle sodium channel gene in paramyotonia congenita. Cell. 68:769-774.

3. Ptacek, L. J., R. Tawil, R. C. Griggs, G. Meola, P. Mcmanis, R. J. Barohn, J. R. Mendell, C. Harris, R. Spitzer, F. Santiago, and M. F. Leppert. 1994. Sodium channel mutations in acetazolamide-responsive myotonia congenita, paramyotonia congenita, and hyperkalemic periodic paralysis. Neurology. 44:1500-1503.

4. Ricker, K., R. T. Moxley, R. Heine, and F. Lehmann-Horn. 1994. Myotonia fluctuans: A third type of muscle sodium channel disease. Arch. Neurol. 51:10951102.

5. Jackman, W. M., K. J. Friday, J. L. Anderson, E. M. Aliot, M. Clark, and R. Lazzaro. 1988. The long QT syndromes: a critical review, new clinical observations and a unifying hypothesis. Prog. Cardiovasc. Dis. 31:115-172.

6. Keating, M., D. Atkinson, C. Dunn, K. Timothy, G. M. Vincent, and M. Leppert. 1991. Linkage of a cardiac arrhythmia, the long QT syndrome, and the Harvey ras-1 gene. Science (Wash. DC). 252:704-706.

7. Jiang, C., D. Atkinson, J. A. Towbin, I. Splawski, M. H. Lehmann, H. Li, K. Timothy, R. T. Taggart, P. J. Schwartz, G. M. Vincent, A. J. Moss, and M. T. Keating. 1994. Two long QT syndrome loci map to chromosomes 3 and 7 with evidence for further heterogeneity. Nature Genet. 8:141-147.

8. Curran, M. E., I. Splawski, K. W. Timothy, M. Vincent, E. D. Green, and M. T. Keating. 1995. A molecular basis for cardiac arrhythmia: HERG mutations cause Long QT Syndrome. Cell. 80:795-803.

9. Wang, Q., J. Shen, I. Splawski, D. Atkinson, Z. Li, J. L. Robinson, A. J. Moss, J. A. Towbin, and M. T. Keating. 1995. SCN5A mutations associated with an inherited cardiac arrhythmia, Long QT Syndrome. Cell. 80:805-811.

10. Gwathmey, J. K., L. Copelas, R. MacKinnon, F. J. Schoen, M. D. Feldman, W. Grossman, and J. P. Morgan. 1987. Abnormal intracellular calcium handling in myocardium from patients with end-stage heart failure. Circ. Res. 61:70-76.

11. Beuckelmann, D. J., M. Naebauer, and E. Erdmann. 1992. Intracellular calcium handling in isolated ventricular myocytes from patients with terminal heart failure. Circulation. 85:1046-1055.

12. Tomaselli, G. F., D. J. Beuckelmann, H. G. Calkins, R. D. Berger, P. D. Kessler, J. H. Lawrence, D. Kass, A. M. Feldman, and E. Marban. 1994. Sudden cardiac death in heart failure: the role of abnormal repolarization. Circulation. 90:2534-2539.

13. Beuckelmann, D. J., M. Naebauer, and E. Erdmann. 1993. Alterations of $\mathrm{K}^{+}$currents in isolated human ventricular myocytes from patients with terminal heart failure. Circ. Res. 73:379-385.

14. Naebauer, M., D. J. Beuckelmann, and E. Erdmann. 1993. Characteristics of transient outward current in human ventricular myocytes from patients with terminal heart failure. Circ. Res. 73:386-394.

15. Weidmann, S. 1951. Effect of current flow on the membrane potential of cardiac muscle. J. Physiol. (Lond.). 115:227-236.

16. Wolff, J. A., R. W. Malone, P. Williams, W. Chong, G. Acsadi, A. Jani, and P. L. Felgner. 1990. Direct gene transfer into mouse muscle in vivo. Science (Wash. DC). 247:1465-1468.

17. Buttrick, P. M., A. Kass, R. N. Kitsis, M. L. Kaplan, and L. A. Leinwand. 1992. Behavior of genes directly injected into the rat heart in vivo. Circ. Res. 70:193-198.

18. Lin, H., M. S. Parmacek, G. Morle, S. Bolling, and J. M. Leiden. 1990. Expression of recombinant genes in myocardium in vivo after direct injection of DNA. Circulation. 82:2217-2221.

19. Stratford-Perricaudet, L. D., I. Makeh, L. D. Perricaudet, and P. Briand. 1992. Widespread long-term gene transfer to mouse skeletal muscles and heart. J. Clin. Invest. 90:626-630.

20. Quantin, B., L. D. Perricaudet, S. Tajbakhsh, and J.-L. Mandel. 1992. Adenovirus as an expression vector in muscle cells in vivo. Proc. Natl. Acad. Sci. USA. 89:2581-2584.

21. Kass-Eisler, A., E. Falck-Pedersen, M. Alvira, J. Rivera, P. M. Buttrick, B. A. Wittenberg, L. Cipriani, and L. A. Leinwand. 1993. Quantitative determination of adenovirus-mediated gene delivery to rat cardiac myocytes in vitro and in vivo. Proc. Natl. Acad. Sci. USA. 90:11498-11502.

22. Kirshenbaum, L. A., W. R. MacLellan, W. Mazur, B. A. French, and M. D. Schneider. 1993. Highly efficient gene transfer into adult ventricular myocytes by recombinant adenovirus. J. Clin. Invest. 92:381-387.

23. Ragot, T., N. Vincent, P. Chafey, E. Vigne, H. Gilgenkrantz, D. Couton, 
J. Cartaud, P. Briand, J.-C. Kaplan, M. Perricaudet, and A. Kahn. 1993. Efficient adenovirus-mediated transfer of a human minidystrophin gene to skeletal muscle of $\mathrm{mdx}$ mice. Nature (Lond.). 361:647-650.

24. Guzman, R. J., P. Lemarchand, R. G. Crystal, S. E. Epstein, and T. Finkel. 1993. Efficient gene transfer into myocardium by direct injection of adenovirus vectors. Circ. Res. 73:1202-1207.

25. Bett, A. J., W. Haddara, L. Prevec, and F. L. Graham. 1994. An efficient and flexible system for construction of adenovirus vectors with insertions or deletions in early regions 1 and 3. Proc. Natl. Acad. Sci. USA. 91:8802-8806.

26. Yellen, G., M. E. Jurman, T. Abramson, and R. MacKinnon. 1991. Mutations affecting internal TEA blockade identify the probably pore-forming region of a $\mathrm{K}^{+}$channel. Science (Wash. DC). 251:939-942.

27. Graham, F. L., and L. Prevec. 1991. Manipulation of adenovirus vectors. In Methods in Molecular Biology, Vol. 7. Gene Transfer and Expression Protocols.

E. J. Murray, editor. The Humana Press, Inc., Clifton, New Jersey. 109-128.

28. Bett, A. J., L. Prevec, and F. L. Graham. 1993. Packaging capacity and stability of human adenovirus type 5 vectors. J. Virol. 67:5911-5921.

29. McGrory, W. J., D. S. Bautista, and F. L. Graham. 1988. A simple technique for the rescue of early region I mutations into infectious human adenovirus type 5. Virology. 163:614-617.

30. Herz, J., and R. D. Gerard. 1993. Adenovirus-mediated transfer of low density lipoprotein receptor gene acutely accelerates cholesterol clearance in normal mice. Proc. Natl. Acad. Sci. USA. 90:2812-2816.
31. Simpson, P., and S. Savion. 1982. Differentiation of rat myocytes in single cell cultures with and without proliferating nonmyocardial cells: cross-striations, ultrastructure, and chronotropic response to isoproterenol. Circ. Res. 50:101-116.

32. Schanne, O. F., E. Ruiz-Ceretti, C. Rivard, and D. Chartier. 1977. Determinants of electrical activity in clusters of cultured cardiac cells from neonatal rats. J. Mol. Cell. Cardiol. 9:269-283.

33. Mohamed, S. N., R. Holmes, and C. R. Hartzell. 1983. A serum-free, chemically-defined medium for function and growth of primary neonatal rat heart cell cultures. In Vitro. 19:471-478.

34. Graham, F. L., J. Smiley, W. C. Russell, and R. Nairn. 1977. Characteristics of a human cell line transformed by DNA from human adenovirus type $5 . J$. Gen. Virol. 36:59-72.

35. Perez-Garcia, M. T., T. J. Kamp, and E. Marban. 1995. Functional properties of cardiac L-type calcium channels transiently expressed in HEK293 cells: Roles of $\alpha 1$ and $\beta$ subunits. J. Gen. Physiol. 105:1-18.

36. Moule, S. K. and J. D. McGivan. 1990. Regulation of the plasma membrane potential in hepatocytes--mechanism and physiological significance. Biochim. Biophys. Acta. 1031:383-397.

37. Thompson, L. 1992. Clinical medicine: at age 2, gene therapy enters a growth phase. Science (Wash. DC) 258:744-746.

38. Yang, Y. P., F. A. Nunes, K. Berencsi, E. Gonczol, J. F. Engelhardt, and J. M. Wilson. 1994. Inactivation of E2a in recombinant adenoviruses improves the prospect for gene therapy in cystic fibrosis. Nature Genet. 7:362-369. 